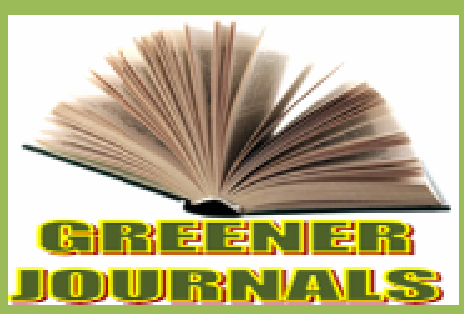

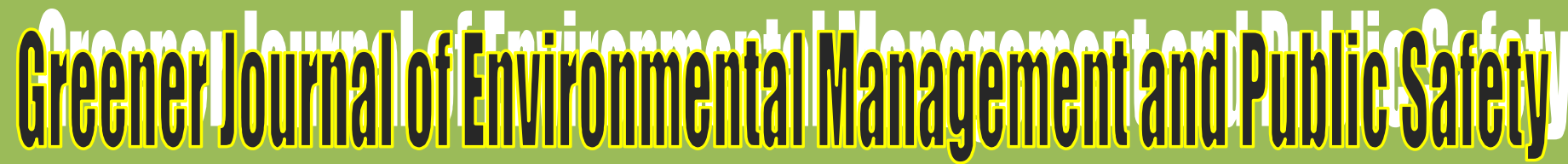

ISSN: 2354-2276

Submitted: 14/01/2016

Accepted: 23/01/2016

Published:30/04/2015

DOI: http://doi.org/10.15580/GJEMPS.2016.2.011416007

Detecting Forest

Degradation in Old

Oyo National Park in

Nigeria Using Remote

Sensing and GIS

By

Omolere OS

Alaga AT

Mohammed SO

Gajere EN

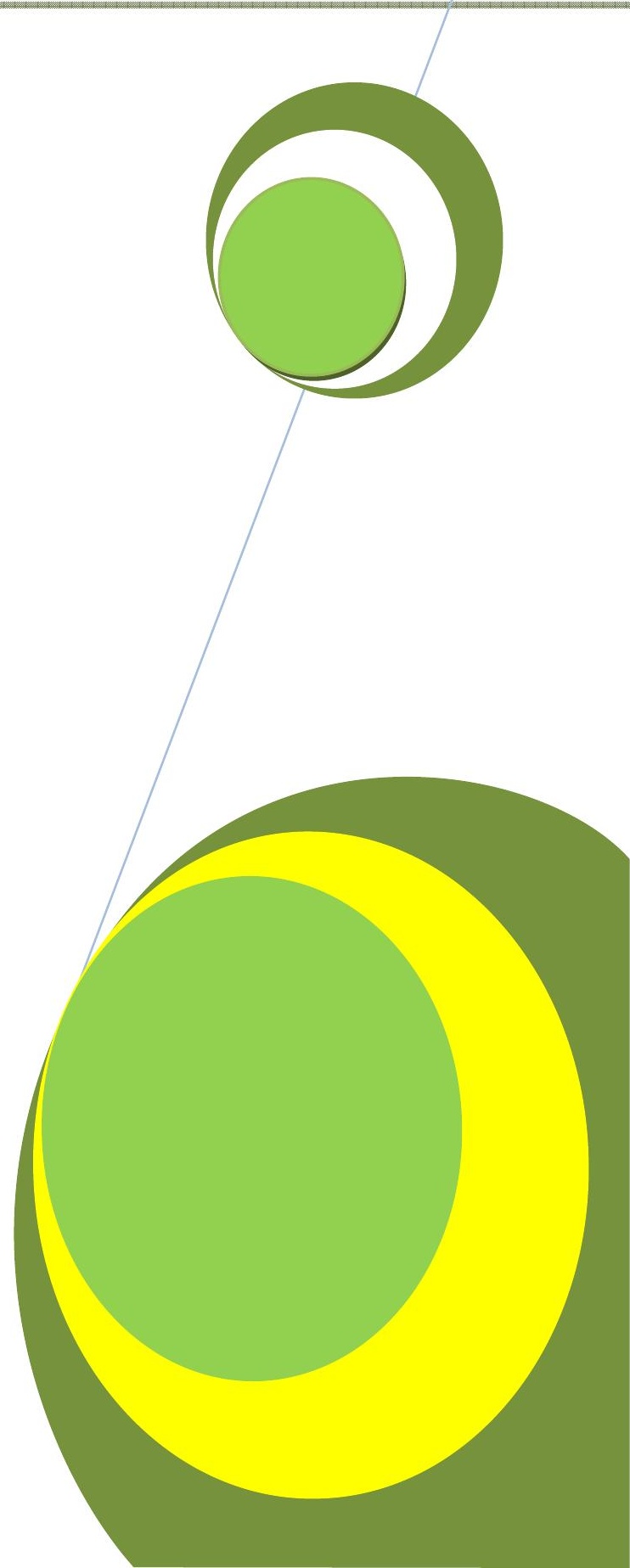


Research Article (DOI: http://doi.org/10.15580/GJEMPS.2016.2.011416007)

\title{
Detecting Forest Degradation in Old Oyo National Park in Nigeria Using Remote Sensing and GIS ${ }^{1 \star}$ Omolere OS, ${ }^{1}$ Alaga AT, ${ }^{2}$ Mohammed SO, ${ }^{2}$ Gajere EN
}

\author{
${ }^{1}$ Co-Operative Information Network. (Copine), Obafemi Awolowo University, Ile-Ife. \\ ${ }^{2}$ National Space Research and Development Agency.Abuja, Nigeria (Nasrda). \\ *Corresponding Author's Email: Sesan205 @yahoo .com
}

\begin{abstract}
Abundant fauna and flora resources in Nigeria are being threatened due to the increasing rate of anthropogenic activities across the protected areas in the country. This study examined anthropogenic activities threatening the natural resources considered to be of ecotourism value in Old Oyo National Park. The research also aimed at detecting the level of forest degradation from 1990 to 2014.

A time series Landsat data from 1990 to 2014 for Old Oyo National park was used, a maximum likelihood classification algorithm was employed.

In order to obtain the area extent (in hectares) of the resulting land use / land cover type for each study year and for subsequent comparison, the GIS analysis in database query (AREA) of Idrisi Taiga was carried out. Tabulation and area calculations provided a comprehensive dataset in terms of the overall land scope and the type and the amount of changes that have occurred.

Remote sensing technology in combination with Geographic Information System can render reliable information on landuse dynamics. This study will examine the integration of geospatial technique in examining the level of forest degradation around Old Oyo National park. Landsat TM for 1990, TM 2000 and Landsat 8 of 2014 would be used to determine the level of forest degradation. Markov chain prediction for a period of twenty years would be performed. This is to predict the state of the forest in the next twenty (20) years, from 2000 to 2020 . Other analysis will also be performed, such as area calculation, gain and loss using Land change modeller, overlay and image differencing.
\end{abstract}

Keywords: Degradation, Forest, National Park.

\subsection{INTRODUCTION}

Nigeria's forest produces a wide range of goods and services for the local population. In addition to contributing to the national economy, the forests support some of the poorest members of the society; mostly the rural areas, by providing food, environmental services and opportunities to generate income.

The important functions of the forest include regulation of hydrological systems, erosion control, control of desertification, improving air quality, and the provision of habitat to a myriad of life forms. The forestry sector plays a critical role in addressing both local and national environmental problems in Nigeria. The forests are substantial sources of re-investigable capital and income and with great potential as the foundation for industrialization and enhancement of the stability of the rural population (Famuyideet al, 2005). It is estimated that at the global level, forestry formerly contributes some 2 percent to world GDP or more than USD 600 billion per annum (FAO, 1997; Lomborg; 2001; Faleyimu, 2006). However, the actual contribution of forests to the world economy may be much higher, though extremely difficult to quantify.

A study was carried out and it was observed that Nature estimated the global value of goods and services that forest ecosystems provide from timber to climate regulation to water supply to recreation is estimated at US \$ 4.7 trillion a year, or more than a quarter of that year's world GNP of US \$ 18 trillion (Constanza et al (1997); World Bank (2002).

There are many definitions of the term forestry. These definitions differ based on the emphasis or concerns of different people; A legal definition is different from an ecological definition. The perspective of the economist differs from that of a geographer, but all definitions stress the importance of trees in the system. Few definitions covering the three perspectives may suffice; Museum link of Illinois, United States of America defines forest "as an ecosystem or assemblage of ecosystems dominated by trees and other woody vegetation". It goes further to state that the living parts of the a forest include trees, shrubs, vines, grasses and other herbaceous, (non-woody) plants, mosses, algae, 
fungi, insects, mammals, birds, reptiles, amphibians, and microorganisms living on the plants and animals and in the soil, water, and minerals, to make up what we know as a forest.

The aim of the study is to examine the nature of forest degradation around Old Oyo National park and develop a spatial decision support information system for the management of National parks.

\section{The specific objectives of the study are:}

$>$ To evaluate the nature of vegetation degradation of the park over 25 years.

$>$ To identify primary agents of vegetation degradation.

> To predict the status of Old Oyo National Park in the year 2020 if the current management system continues"

\subsection{MATERIALS AND METHODS}

This chapter describes the methodology employed in carrying out this study. In assessing the level of vegetation degradation, the study relied on landuse/ landcover change of the area.

The procedures for the acquisition and processing of the remote sensing data were discussed. Field survey information was obtained and used to validate the remotely sensed data.

\subsection{DATA SOURCE}

The topographic map covering the National park and its surroundings for 1994 was obtained. The topographic map used was obtained from co-operative information network (COPINE), Obafemi Awolowo University campus, Ile-Ife. Satellite data covering the study area and its surroundings for 1990, 2000 and 2005 were obtained for the study from global land cover facility (GLCF). The detail of the characteristic of these images is shown in Table 1

Table 1: Data Used

\begin{tabular}{|c|l|l|l|}
\hline $\begin{array}{l}\text { LANDSAT } \\
\text { SCENE }\end{array}$ & $\begin{array}{l}\text { ACQUISITION } \\
\text { DATE }\end{array}$ & $\begin{array}{l}\text { LOCATION ON } \\
\text { WRS }\end{array}$ & $\begin{array}{l}\text { ACTUAL SPATIAL } \\
\text { RESOLUTION }\end{array}$ \\
\hline TM & $27 / 12 / 1990$ & P191R54 & $28.5 \mathrm{~m} \times 28.5 \mathrm{~m}$ \\
\hline TM & $02 / 06 / 2000$ & P191R54 & $28.5 \mathrm{~m} \times 28.5 \mathrm{~m}$ \\
\hline LANDSAT 8 & $18 / 11 / 2014$ & P191R54 & $28.5 \mathrm{~m} \times 28.5 \mathrm{~m}$ \\
\hline
\end{tabular}

A map of landuse/landcover of the area will be generated with road network and settlement, the road net and settlement shape files will be overlaid on the classified images for the three different years.

Vegetation classification is widely accepted as an appropriate analytical technique for estimating changes in vegetation cover and quality of standing biomass. Such classification enables an appreciation of the details of physical and structural changes taking place within a vegetation unit such as forest reserve (Cannon et al., Ikhuoria 1999; ERGO, 1994; Salami, 1999). The supervised classification of the imageries was performed using Maximum Likelihood algorithm that is based on Gaussian normal distribution (Swain and Davis, 1978) as cited in Oyinloye, 2008.

\subsection{Selection Of Feature Classes}

An eight category Land_use/ Land_cover was employed as a result of the restrictions by low spatial resolution of LANDSAT data. These categories which were equivalent to level one of the United States Geological Survey (USGS) scheme were:

1. Extensive field cropland

2. Intensive markets garden

3. New agricultural land 
4. Steppe shrubland and grassland

5. Mixed deciduous and evergreen forest

6. Urban or built-up land

7. Bog and Marsh land

8. Rivers, stream and lake

The classes were modify to suit my study, these eight categories were reduced to seven classes namely: forest, cultivation, riparian, water body, built-up, bare surface, water body.

\subsection{Data Processing}

The satellite data were processed using ERDAS 9.2, Arc GIS and IDRISI TAIGA 16.0 version. The satellite images were stalk and enhanced for proper visualization and interpretation. The region of interest was subseted for the three images.

The bands used for the study are bands 4,3 , and 2, band 4 represents the reflective - infrared, and it covers the wavelength of $0.76-0.90 \mathrm{~nm}$.

\subsection{RESULTS}

Table 2: Changein Areaof Land Use/Land Coverin sq. km

\begin{tabular}{|l|l|l|l|}
\hline classes & 1990 & $\mathbf{2 0 0 0}$ & $\mathbf{2 0 1 4}$ \\
\hline Forest & 281.8776 & 414.1013 & 587.1177 \\
\hline Settlement & 71.4918 & 133.3138 & 622.6146 \\
\hline Shrub land & 5549.0816 & 3051.0319 & 937.3923 \\
\hline Riparian & 1840.4886 & 4687.9439 & 2358.3627 \\
\hline Cultivation & 6618.6419 & 5806.1953 & 8019.23 \\
\hline Bare surfaces & 35.6651 & 62.5676 & 206.8848 \\
\hline Water body & 2.9590 & 42.4994 & 100.4820 \\
\hline Burnt land & 2647.9148 & 850.4671 & 2276.2242 \\
\hline
\end{tabular}
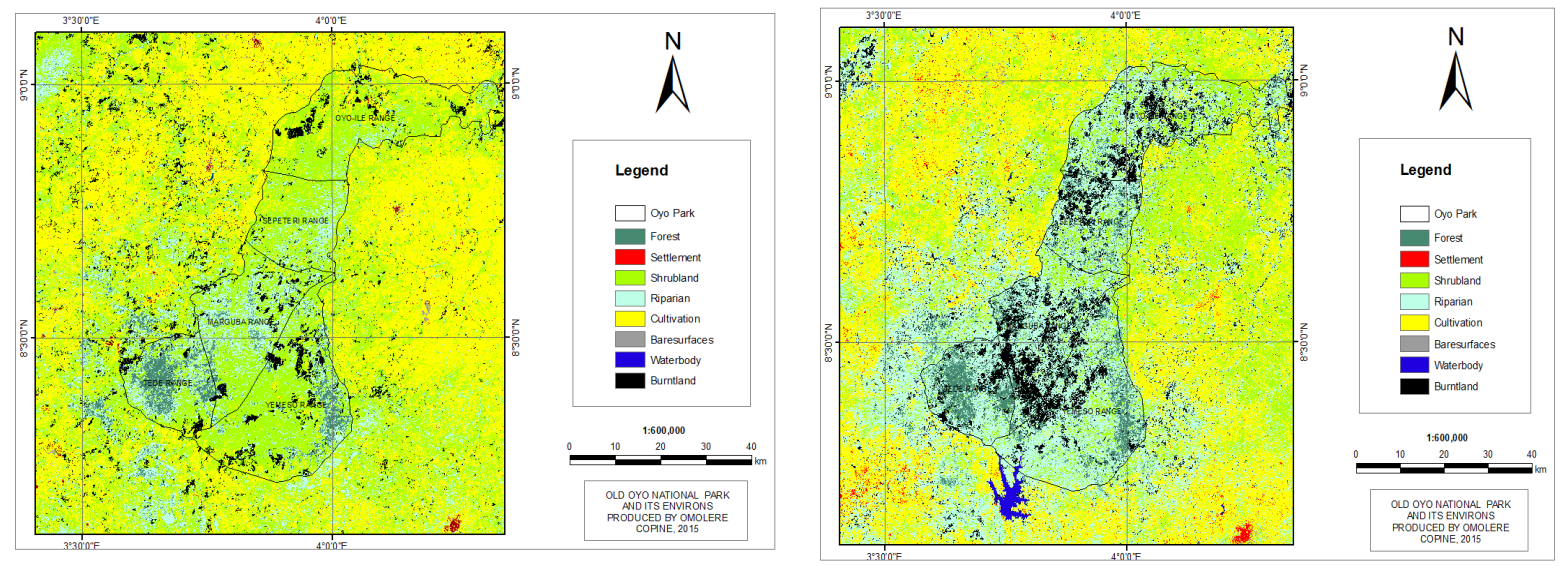

Figure 1.1: COMPOSED MAP OF OLD OYO NATIONAL PARK 1990 


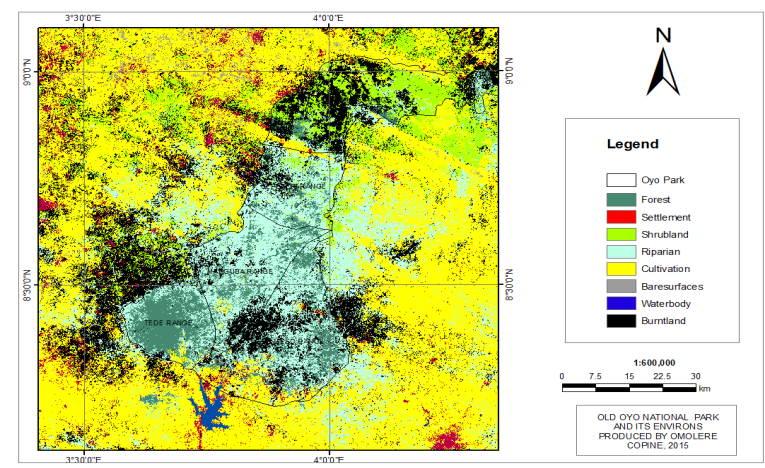

Figure 1.3: Composed Map of Old Oyo National Park 1990
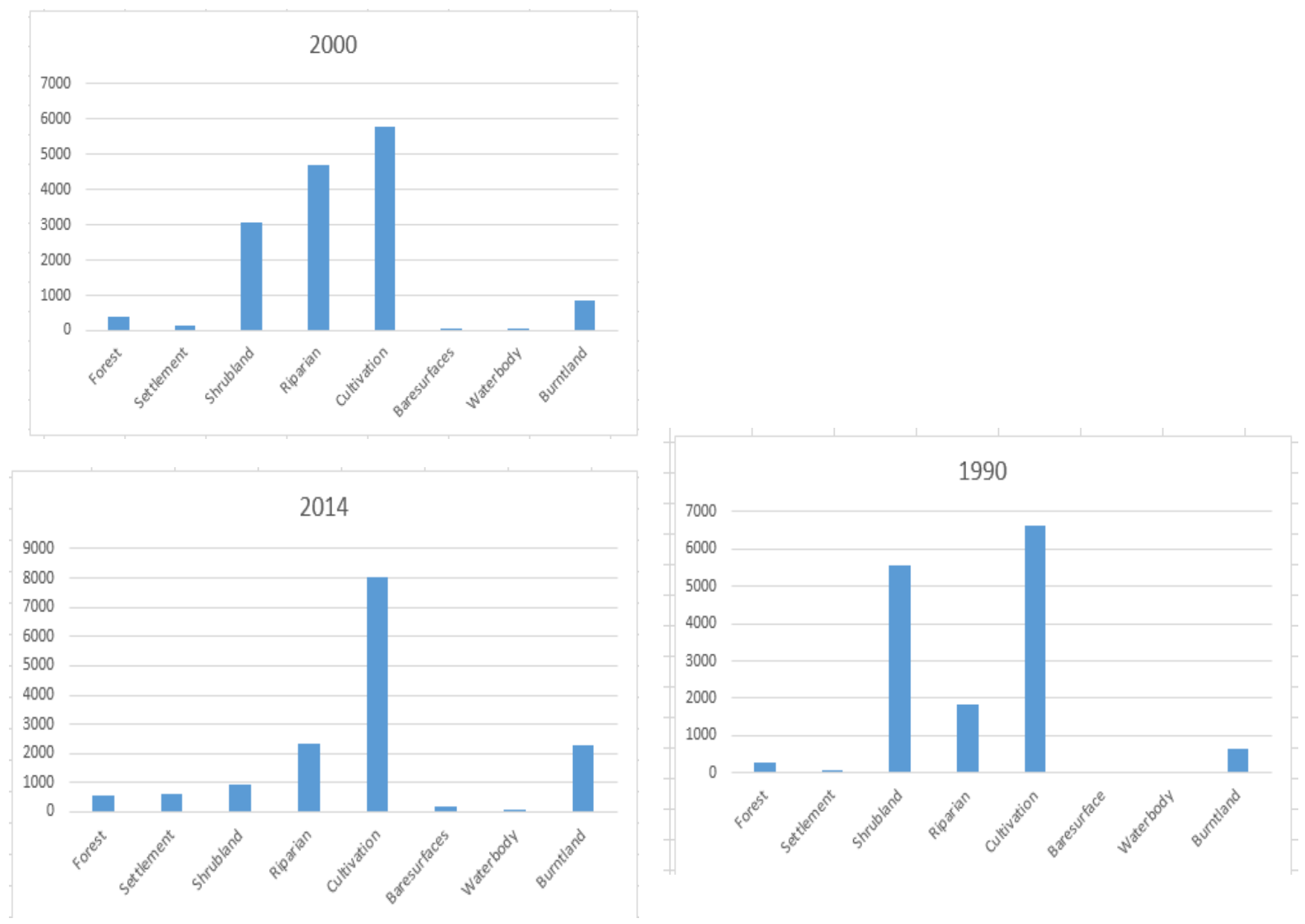

Figure 1.4: Histogram Showing Changes in Landuse/Land Cover from 1990, 2000 and 2014

\subsection{DISCUSSIONS}

In order to obtain the area extent (in hectares) of the resulting land use / land cover type for each study year and for subsequent comparison, the GIS analysis in database query (AREA) of Idrisi Taiga was carried out. Tabulation and area calculations provided a comprehensive dataset in terms of the overall land scope and the type and the amount of changes that have occurred. Table 2 shows the spatial extent of land cover in hectares 1990, 2000 and 2014.

From 1990 to 2014, settlement areas in the Oyo National park expanded by 622.6146 hectares at the expense of other land cover types. Areas occupied by water body were also seen to increase by 100.4820 hectares, this is believed to be due to the construction of reservoir in the area and increase in rainfall as a result of 
climate change. The major river serving the park is the Ogun river before a reservoir was constructed in 1991. In 2000, the forest reserve was highly depleted (Table 2). However, proper management sustainability was seen with drastic increase in forest area in 2014 (587.1177) hectares. Old Oyo National park was being managed by two communities, that is the Oyo-lle and Oke Ogun before the National park was handed over to the Federal government of Nigeria.

The result proves that dynamics in the deforestation pattern in tropical environment are as a result of biophysical and human activities in accordance with Salami et. al., 1999; Oyinloye 2003; Ogundele et. al., 2007 and Fasona et. al., 2005.

There have been tremendous changes in some of the lands used in the area. This was as a result of management strategies employed for the proper management of the park. Some of strategies are:

1) Employment opportunities for the youths in the host communities using Federal character.

2) Giving incentives to women in the host communities to engage them in other businesses rather than destroying the forest for fuel wood.

3) Dividing the National park into five ranges with two security post mounted in each of the ranges for proper monitoring.

4) Provision of hilux van and land rovers for land survey.

5) A buffer zone of $2 \mathrm{kms}$ away from the forest for sitting of settlement.

Table 3: Land Change Modeler

\begin{tabular}{|l|l|l|}
\hline CLASSES & LOSSES sq.km & GAIN sq.km \\
\hline Burntland & -595.27 & 797.83 \\
\hline Waterbody & -2.18 & 41.72 \\
\hline Baresurfaces & -32.28 & 59.18 \\
\hline Cultivation & -2905.23 & 2092.79 \\
\hline Riparian & -872.91 & 3720.36 \\
\hline Shrubland & -4392.92 & 1894.88 \\
\hline Settlement & -56.76 & 118.58 \\
\hline Forest & -139.58 & 271.81
\end{tabular}

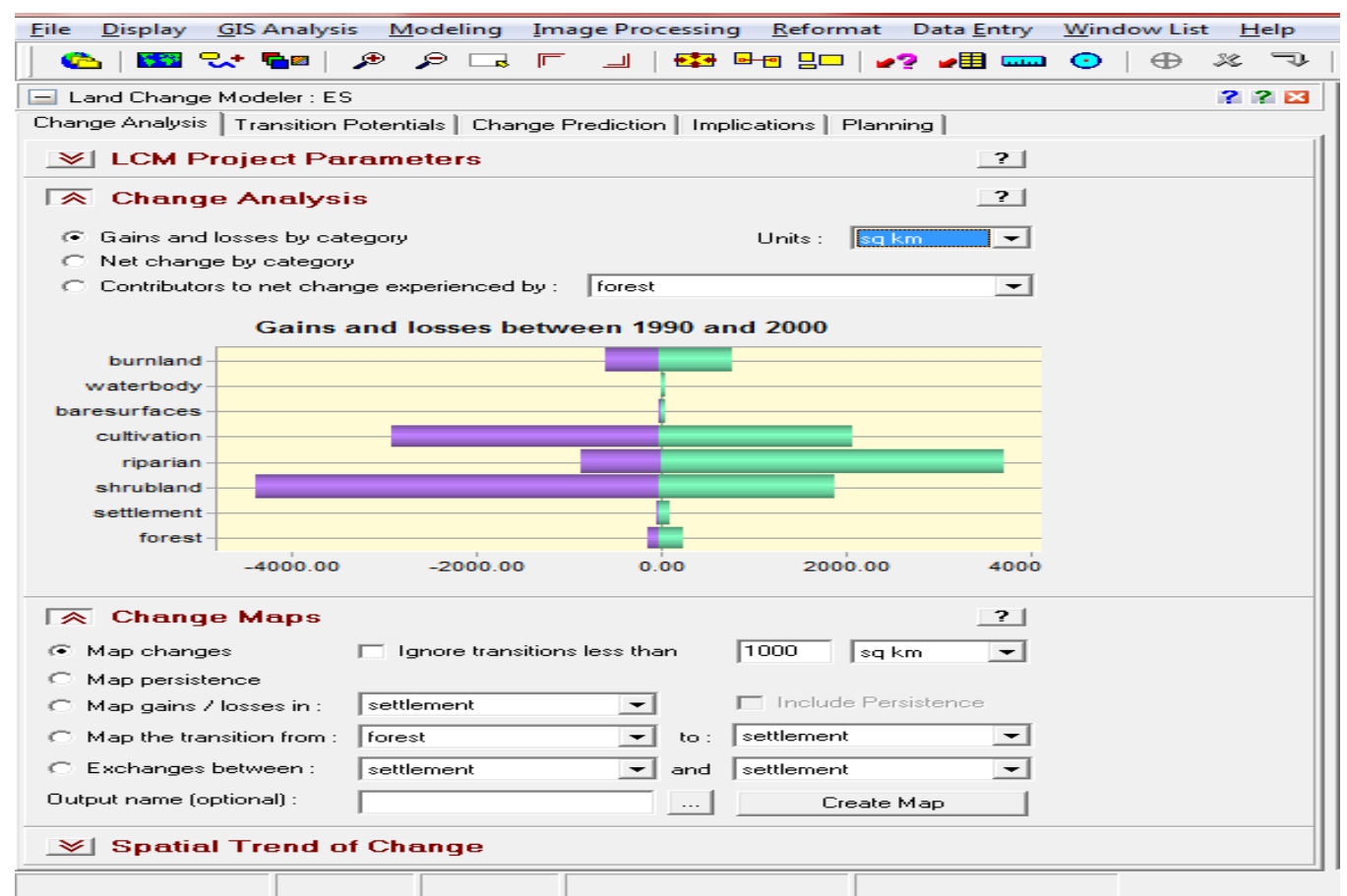

Figure 1.5: Gain and loss between1990-2000 


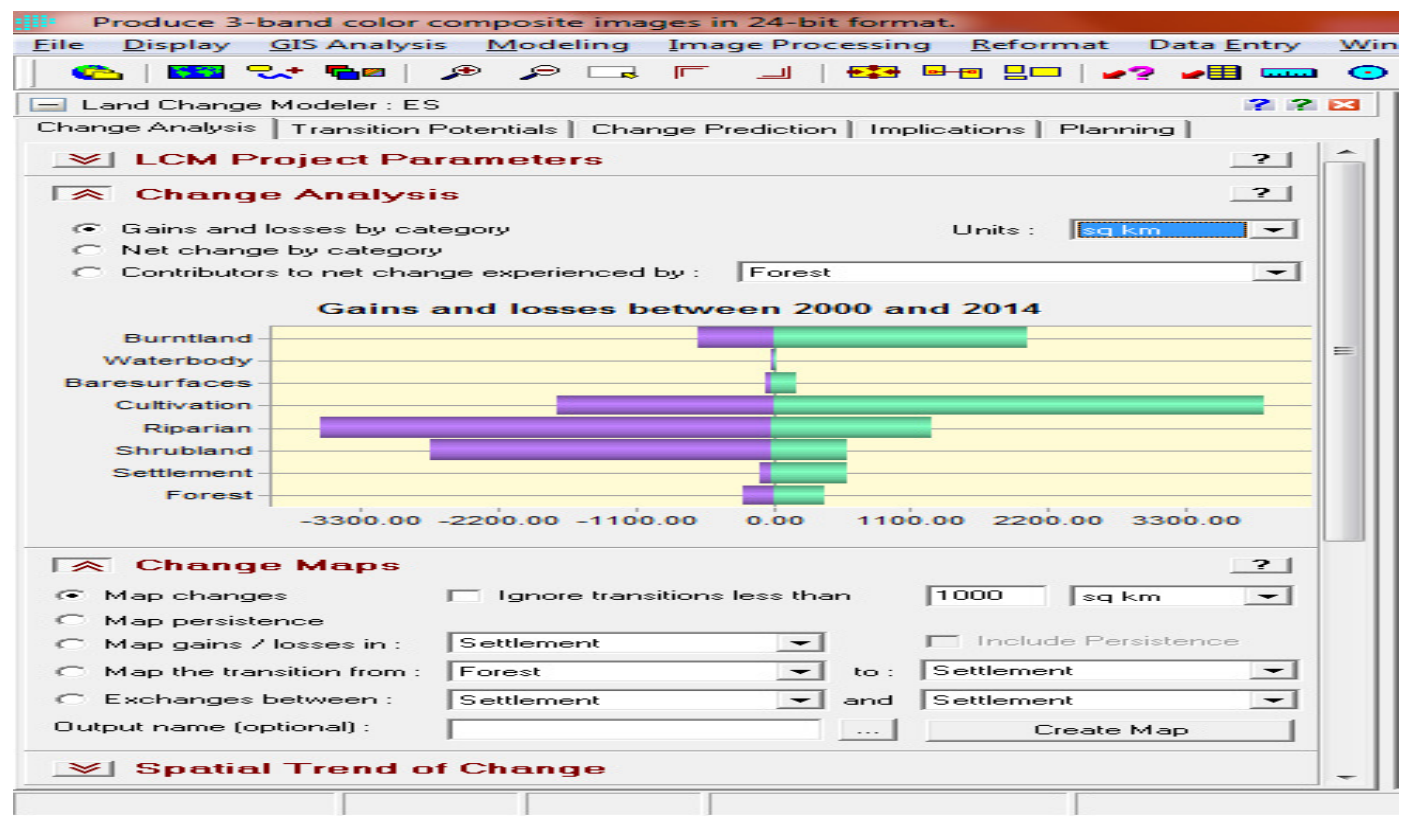

Figure 1.6: Gain and loss between2000-2014

\subsection{DISCUSSION}

The Land Change Modeler (LCM) application within idrisi provides a suite of tools for land change research in a simple and automated workflow. It is sequentially organized around major task areas,land cover change analysis and prediction, estimation of forest areas.

Land is utilized for multiple purposes and it is critical that land cover change be monitored for both its negative and positive consequences. The use of land involves various stakeholders, often bringing differing impacts. It is therefore of the utmost importance that the land cover change analysis and prediction process account for as many components and variables as possible if it is to be a useful and effective planning tool. Where is the land changing and will it continue to change? What is the quantity of change? What is driving land cover change? Figure 1.5 shows the gain and loses of the forest between 1990-2000.

It was found that cultivation, farmland and shrubland increased tremendously in size from 1990 to 2000 , forest gained a total number of 271.81 hectares and loss to cultivation and shrubland with 2509.23 and -4392.92 hectares respectively. This is as a result of vegetation classes being converted to farmlands land cover change analysis and prediction, estimation of forest area.

In figure 1.6, it shows the gain and loss between 2000 and 2014, the purple color shows the loss which is in negative while the green color shows the gain which gives a positive sign.

\begin{tabular}{|c|c|c|c|c|c|c|c|c|}
\hline & & Table & Transi & n Prok & bility Ma & trix & & \\
\hline CLASSES & $c 1$ & $\mathrm{c} 2$ & c3 & c4 & $c 5$ & c6 & c7 & c8 \\
\hline Forest & 0.1294 & 0.0306 & 0 & 0.2359 & 0.4409 & 0 & 0.0071 & 0.1562 \\
\hline Settlement & 0.0119 & 0.0495 & 0.0661 & 0.11 & 0.5954 & 0.3332 & 0.0001 & 0.1338 \\
\hline Shrubland & 0.0365 & 0.396 & 0.0593 & 0.1606 & 0.5494 & 0.0101 & 0.0051 & 0.1393 \\
\hline Riparian & 0.0682 & 0.027 & 0.0143 & 0.2272 & 0.5222 & 0 & 0.005 & 0.1361 \\
\hline Cultivation & 0.0273 & 0.0443 & 0.079 & 0.1425 & 0.5319 & 0.0182 & 0.0011 & 0.1558 \\
\hline $\begin{array}{l}\text { Baresurface } \\
\text { s }\end{array}$ & 0.234 & 0.0418 & 0.071 & 0.1334 & 0.5605 & 0.0208 & 0.0008 & 0.1484 \\
\hline Wetland & 0.0678 & 0.0056 & 0.064 & 0.2437 & 0.3871 & 0.0046 & 0 & 0.2273 \\
\hline Burntland & 0.0423 & 0.0512 & 0.0793 & 0.1077 & 0.5199 & 0.0243 & 0.002 & 0.1733 \\
\hline
\end{tabular}


Table 5: Predicted Status of Old Oyo National Park in Year 2020

CLASSES PREDICTION IN Sq. km

\begin{tabular}{l|l}
\hline Forest & 906 \\
\hline Settlement & 123 \\
\hline Shrubland & 2817 \\
\hline Riparian & 5407 \\
\hline Cultivation & 4775 \\
\hline Baresurfaces & 62 \\
\hline Waterbody & 21 \\
\hline Burntland & 935 \\
\hline
\end{tabular}

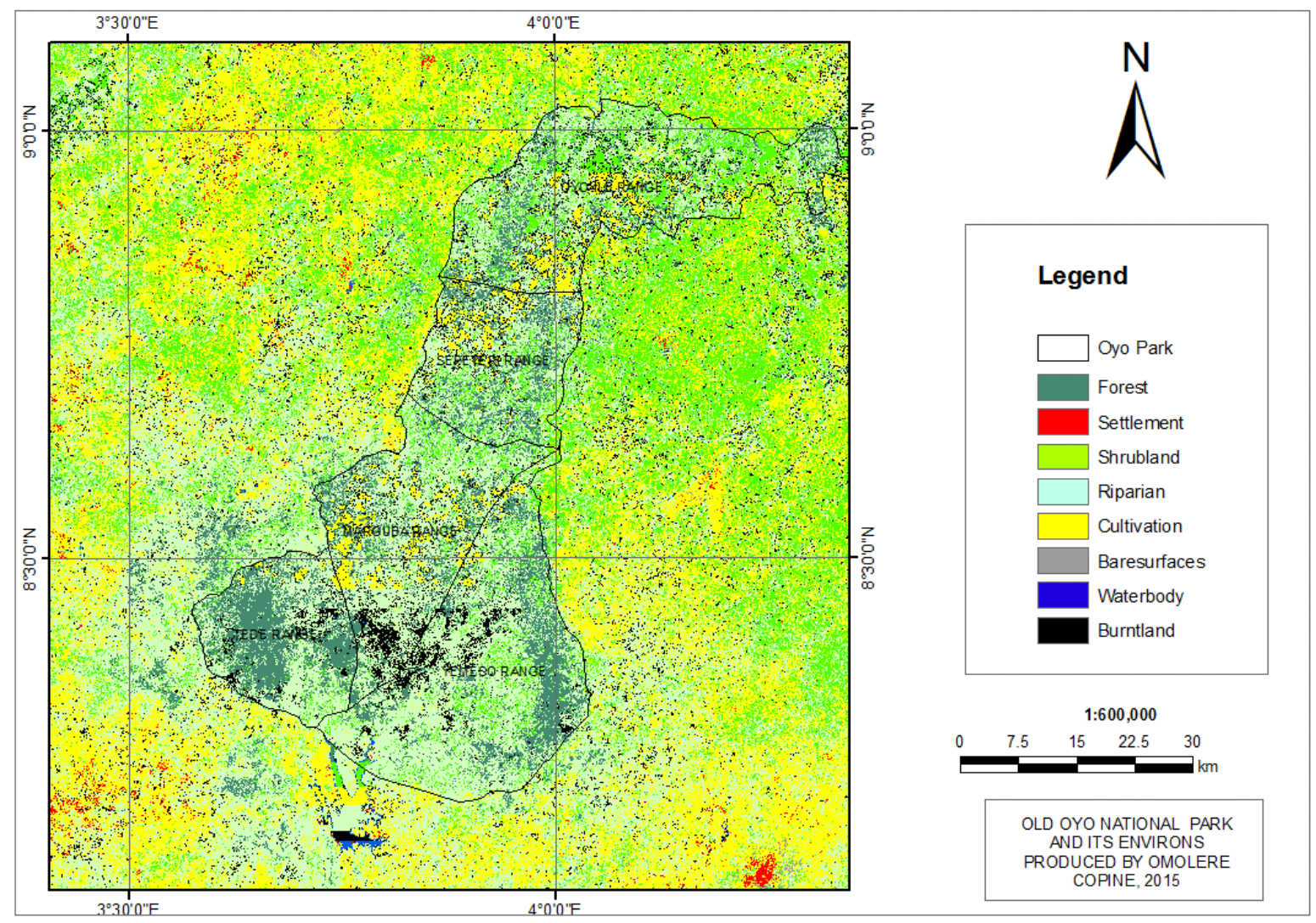

Figure 1.7: Markov Chain Prediction 


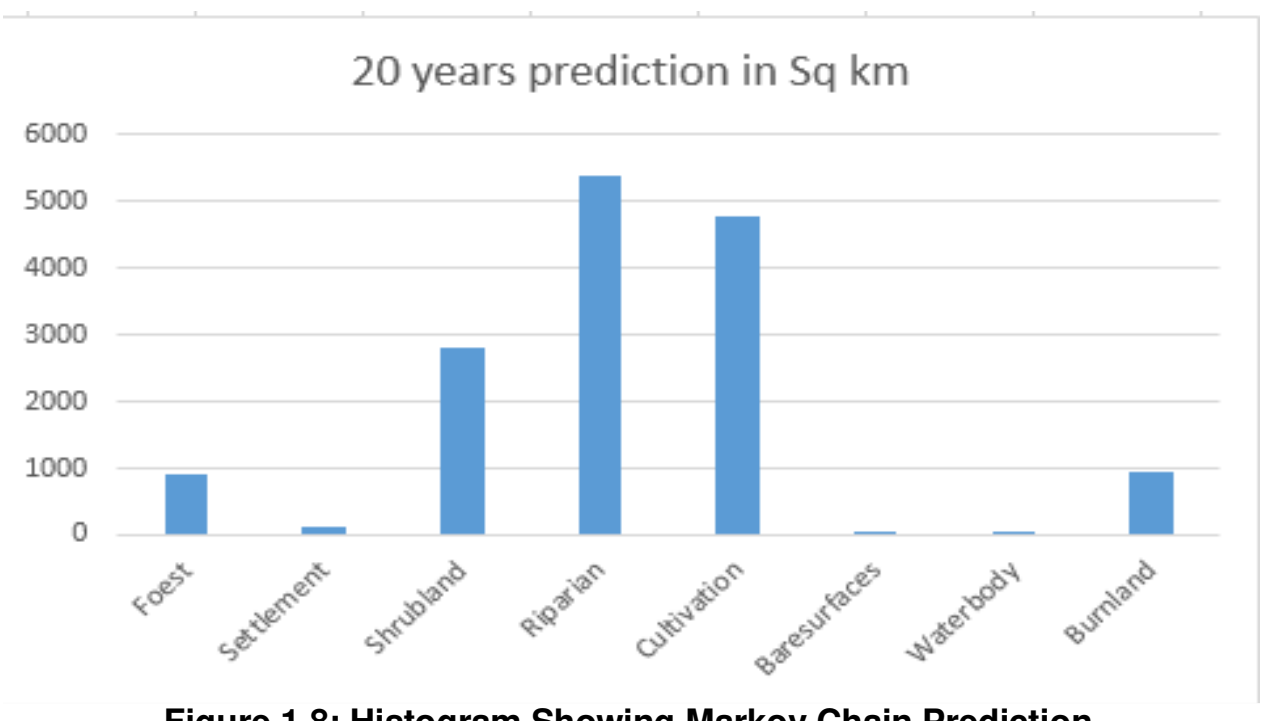

Figure 1.8: Histogram Showing Markov Chain Prediction

\subsection{DISCUSSION}

Table 4 shows the Markov chain prediction for a period of twenty years. A Markovian process is one in which the future state of a system can be modeled purely on the basis of immediately preceding state. The Markov module analyzes a pair of land cover images and outputs a transition probability matrix, a transition area matrix, and a set of conditional probability images (Table 3). The transition probability matrix is a text file that records the probability that each land cover category will change to every other category. The transition areas matrix is a text file that records the number of pixels that are expected to change from each land cover type to each other land cover type over the specified number of time unit (Table 3). In both of these files, the rows represent the older land cover categories and the columns represent the newer categories. The conditional probability images report the probability that each land cover type would be found at each pixel after the specified number of time unit. This is simply an operation in which the future state of a system can be modeled purely on the basis of the immediately preceding state. Markov chain analysis described land use change from one period to another and uses this as the basis to project future change. The Markov module under change/time series analysis under GIS analysis of Idrisi 16.0 was used. The first image (1990) as the earlier image and the second image (2014) as the latter image was inputted. The number of time period between the two images and the number of the projected year from the second image was also inputted. Ten years was used for both numbers of periods (figure 1.6).

Figure 1.6 shows the markov chain prediction map while figure 1.7 shows the future state of the study area in the next twenty years.

\subsection{CONCLUSSION}

This study has demonstrated that the recent advancement in remote sensing and GIS technologies provide powerful tool for mapping and detecting vegetation degradation.

The adoption of various techniques in this research work has helped in providing a system for understanding the complexity of spatial problems, critical evaluation, assessment and also allowing the perception, intuitions judgement - of professionals from diverse fields in planning and decision making process in order to enhance environmental and tourism sustainability. These findings provide quantitative basis and support for forest reserves, management issues and institutional analysis in planning and management of national parks.

Various governments and international organizations in charge of policy formulation for national parks and management should jettison the current centralized management policies which give all power to the central government and their agencies at the expense - of the rural dwellers that live and rely on these resources for their daily livelihood.

The federal government should allow public private partnership (PPP) in the management of national park because government facilities are not properly maintained and managed when kept in government custody. 


\section{REFRENCES}

Faleyimu (2006) Revenue generation in the state Forest service in south west Nigeria. African Journal of General Agriculture. vol. 6 No. 4

Famuyide (2005) Global estimate of the value of ecosystems and their services in Monetary units. vol. 1 pages 50-61

Oyinloye, R. (2003). Generation of impacts of sesitivity index (ESI) map of impacts of ubanization of lbadan, Nigeria, using multi-temporal images. . Ile-Ife Nigeria.: Unpublish MSC Thesis.

Oyinloye, R. \& Salami, A. (1990). Detection of forest reserve incursion in South-western Nigeria from a combination of multi data aerial photographs and high resolution.

Salami, A. T. \& Akinyede, J. (2006). Space technology for monitoring and managing forest in Nigeria,. United Nation committee on peaceful uses of outer space (UNOOSA), (pp. 221-252). Vienna,Austria.

Salami A. T. (1999) Application of Remote sensing and GIS in Land use/ Land cover mapping and change detection In part of south western Nigeria. African Journal of Environmental science and technology vol. (5) pp. 099- 101

Salem, C. \& Vincent. M. (2007). An algebra for multicriteria spatial modelling computers. Enviroment and Urban system, 572-596.

Cite this Article: Omolere OS, Alaga AT, Mohammed SO, Gajere EN (2016). Detecting Forest Degradation in Old Oyo National Park in Nigeria Using Remote Sensing and GIS. Greener Journal of Environmental Management and Public Safety, 5(2):051-059, http://doi.org/10.15580/GJEMPS.2016.2.011416007 